\title{
Granulosal and thecal expression of bone morphogenetic protein- and activin-binding protein mRNA transcripts during bovine follicle development and factors modulating their expression in vitro
}

\author{
Claire Glister, Leanne Satchell and Phil G Knight \\ School of Biological Sciences, University of Reading, Hopkins Building, Whiteknights, Reading RG6 6UB, UK
}

Correspondence should be addressed to P G Knight; Email: p.g.knight@reading.ac.uk

\begin{abstract}
Evidence supports local roles for transforming growth factor $\beta$ superfamily members including activins and bone morphogenetic proteins (BMP) in follicle development. Access of these ligands to signalling receptors is likely modulated by extracellular binding proteins (BP). In this study, we compared ex vivo expression of four BPs (chordin, gremlin, noggin and follistatin) in granulosal (GC) and theca interna (TC) compartments of developing bovine antral follicles (1-18 mm). Effects of FSH and IGF on BMP and BP expression by cultured GC, and effects of LH and BMPs on BP expression by cultured TC were also examined. Follicular expression of all four BP transcripts was higher in GC than TC compartments $(\boldsymbol{P}<\mathbf{0 . 0 0 1})$ a finding confirmed by immunohistochemistry. Follicle category affected $(\boldsymbol{P}<0.01)$ gremlin and follistatin $\mathrm{mRNA}$ abundance, with a significant cell-type $\times$ follicle category interaction for chordin, follistatin and noggin. Noggin transcript abundance was lower $(P<0.05)$ in GC of large 'E-active' than 'E-inactive' follicles while follistatin $m R N A$ level was higher $(P<0.01)$. FSH enhanced CYP19, FSHR, INHBA and follistatin by GC without affecting BMP or BMP-BP expression. IGF increased CYP19 and follistatin, reduced BMP4, noggin and gremlin but did not affect chordin or FSHR mRNA levels. LH increased TC androgen secretion but had no effect on BMP or BP expression. BMPs uniformly suppressed TC androgen production whilst increasing chordin, noggin and gremlin mRNA levels up to 20-fold $(P<0.01)$. These findings support the hypothesis that extracellular BP, mostly from GC, contribute to the regulation of intrafollicular BMP/activin signalling. Enhancement of thecal BP expression by BMP implies an autoregulatory feedback role to prevent excessive signalling.

Reproduction (2011) 142 581-591
\end{abstract}

\section{Introduction}

During recent years a wealth of investigation has been directed at transforming growth factor $\beta$ (TGFB) superfamily members, in particular the largest subset within the family, the bone morphogenetic proteins (BMP). More than 20 BMPs have been identified in vertebrates and non-vertebrate species and these multifunctional proteins contribute to the regulation of cellular proliferation, differentiation and apoptosis in a variety of tissues, including the ovary (Miyazono et al. 2001, Chen et al. 2004, Shimasaki et al. 2004, Knight \& Glister 2006). A number of BMPs are expressed in theca cells (TC), granulosa cells (GC) and oocytes in a cell- and follicle stage-specific manner and evidence supports their involvement in the regulation of folliculogenesis, ovulation and corpus luteum function (reviews: Shimasaki et al. 2004, Juengel \& McNatty 2005, Knight \& Glister 2006). Recently, Glister et al. (2010) reported a survey of BMP2, BMP4, BMP6 and BMP7 expression in TC and GC throughout bovine antral follicular development and related this to the pattern of expression of type 1 and type 2 signalling receptors. Significant cell-type and follicle stage-dependent changes in expression of individual ligands and receptors were revealed but, in general, changes in receptor transcript abundance were relatively modest, supporting the notion that additional levels of control may be operational to modulate BMP signalling at the local level.

Despite the likely functional importance of BMP signalling within the ovary, few studies have addressed the potential role of extracellular BMP-binding proteins (BP) in modulating BMP access to their signalling receptors on different ovarian cell-types. Much of the research on BMP-BPs has been in the developmental biology field where their crucial roles have been identified in establishing BMP morphogen gradients responsible for embryonic patterning (Thomsen 1997, Balemans \& Van Hul 2002, Chen et al. 2004, Kishigami \& Mishina 2005). To our knowledge no comprehensive surveys of BMP-BP expression throughout ovarian follicle growth have yet been carried out in any species. 
Similarly, information is lacking on the factors (systemic or intraovarian) that potentially modulate expression of BMP-BPs by follicle cells. As such, with the exception of follistatin (predominantly an activin-BP), the significance of secreted BMP-BPs as intrafollicular modulators of BMP action has received little attention.

Follistatin was first isolated by Robertson et al. (1987) from bovine follicular fluid based on its ability to suppress FSH secretion from pituitary cells and was subsequently shown to function by binding activin with high affinity, thus neutralising its bioactivity (Nakamura et al. 1990). Follistatin has also been shown to bind directly to several other TGFB superfamily members, including inhibin (Shimonaka et al. 1991) and BMP2, BMP4, BMP6, BMP7 and BMP15 (Otsuka et al. 2001, Amthor et al. 2002, Glister et al. 2004) albeit with lower affinity. Noggin, a homodimeric glycoprotein, was first isolated from Xenopus embryonic tissues where it blocks BMP action in the dorsal organising centre (Lamb et al. 1993, Smith et al. 1993). Noggin displays a high-affinity association with BMP2 and BMP4, but less so with BMP7 and BMP6; binding directly prevents interaction of ligand with type 1 receptor (Zimmerman et al. 1996). Chordin, a cysteine-rich secreted protein, was also first identified in Xenopus; located in the dorsal organising centre (Sasai et al. 1994, 1995). It also binds directly to BMP2, BMP4 and BMP7 to prevent BMP-receptor interaction. However, the affinity of chordin for BMP4 is some tenfold less than its counterpart noggin (Piccolo et al. 1996). Gremlin belongs to a subfamily of BMP antagonists all of whom contain a characteristic cysteine-rich domain (CAN domain) containing a particular consensus sequence (Avsian-Kretchmer \& Hsueh 2004). As with chordin and noggin, gremlin was first identified in a Xenopus screen for genes with dorsalising activity (Hsu et al. 1998) and has since been shown to regulate murine limb, kidney and lung development (Zuniga et al. 1999, Khokha et al. 2003, Michos et al. 2004). Gremlin can bind to and inhibit BMP2 and BMP4, but does not interact with activin (Hsu et al. 1998). Interestingly, expression of noggin and gremlin is enhanced by the very BMPs they act to inhibit, indicative of negative feedback loops in operation (Kameda et al. 1999, Pereira et al. 2000). In addition, certain isoforms of follistatin, noggin and chordin bind to cell-surface associated heparin-sulphate proteoglycans. This association may serve to limit diffusion and 'action-range' of either antagonist and/or ligand. It may also promote endocytosis and lysosomal degradation of the target ligand (Sugino et al. 1993, 1997, Jasuja et al. 2004).

Given the current lack of information on potential roles of extracellular BMP-BPs in the ovary, the aims of this study were to: i) use RT-qPCR to quantify chordin, noggin, gremlin and follistatin mRNA expression in thecal and granulosal compartments of developing bovine antral follicles; ii) investigate whether in vitro expression of the above BP transcripts by cultured TC and GC is modulated by gonadotrophins or insulin-like growth factor 1 (IGF1) and iii) examine the effect of exogenous BMP2, BMP4, BMP6 and BMP7 on expression of BP transcripts by cultured TC.

\section{Results}

More detailed characteristics of the follicle sample set analysed in this study, including follicular fluid steroid concentrations and relative expression of GC and TC 'marker' transcripts including FSHR, CYP19, LHCGR and CYP17, are documented in our recent companion paper focusing on follicular expression of BMP ligands and receptors (Glister et al. 2010).

\section{mRNA expression profiles for gremlin, chordin, follistatin and noggin in developing follicles}

mRNA transcripts for each of the four BPs were readily detectable in all GC and TC samples with average qPCR $C_{\mathrm{t}}$ values of 26, 28, 26 and 21 for noggin, chordin, gremlin and follistatin respectively. In Fig. 1, the relative abundance of mRNA transcripts for all four BPs examined was greater in GC than TC (two-way ANOVA: effect of cell-type: $P<0.0001)$. Gremlin expression was highest in GC of 1-2 mm follicles and declined progressively as follicles developed to 11-18 $\mathrm{mm}$ (approximately fivefold reduction; $P<0.002$ ); no difference in GC gremlin expression was evident between large oestrogen-active (LEA) and large oestrogen-inactive (LEI) follicles.

Although there was no overall effect of follicle category on the relative abundance of chordin mRNA, a highly significant follicle category $\times$ cell-type interaction $(P<0.0001)$ justified a series of post hoc pairwise comparisons within cell-type. In GC, chordin mRNA abundance fell (approximately sixfold; $P<0.05$ ) as follicles grew from 1-2 to 7-8 $\mathrm{mm}$ but then increased again (approximately sixfold; $P<0.01$ ) between the 9-10 and 11-18 mm (LEA) follicle categories; GC chordin expression did not differ significantly between LEA and LEI follicles although the mean value was $50 \%$ lower in LEI category. In contrast to GC, chordin expression in the TC layer increased from 1-2 to 9-10 mm follicles (approximately twofold; $P<0.05$ ), before falling (approximately threefold; $P<0.01$ ) to its lowest level in LEA follicles; TC chordin expression was approximately fivefold higher $(P<0.01)$ in LEl than in LEA follicles.

Follistatin expression patterns in GC and TC were similar to those for chordin: in GC a progressive decrease between 1-2 and 9-10 $\mathrm{mm}$ was followed by a large increase $(\sim 14$-fold; $P<0.001)$ in LEA follicles. LEI follicles had approximately sevenfold less follistatin mRNA than LEA follicles $(P<0.01)$. In contrast to GC, follistatin expression in TC increased between 1-2 and 9-10 mm follicles, reaching a relative abundance comparable with that in GC of $9-10 \mathrm{~mm}$ follicles. Transcript level then fell $(P<0.05)$ to its lowest level in 


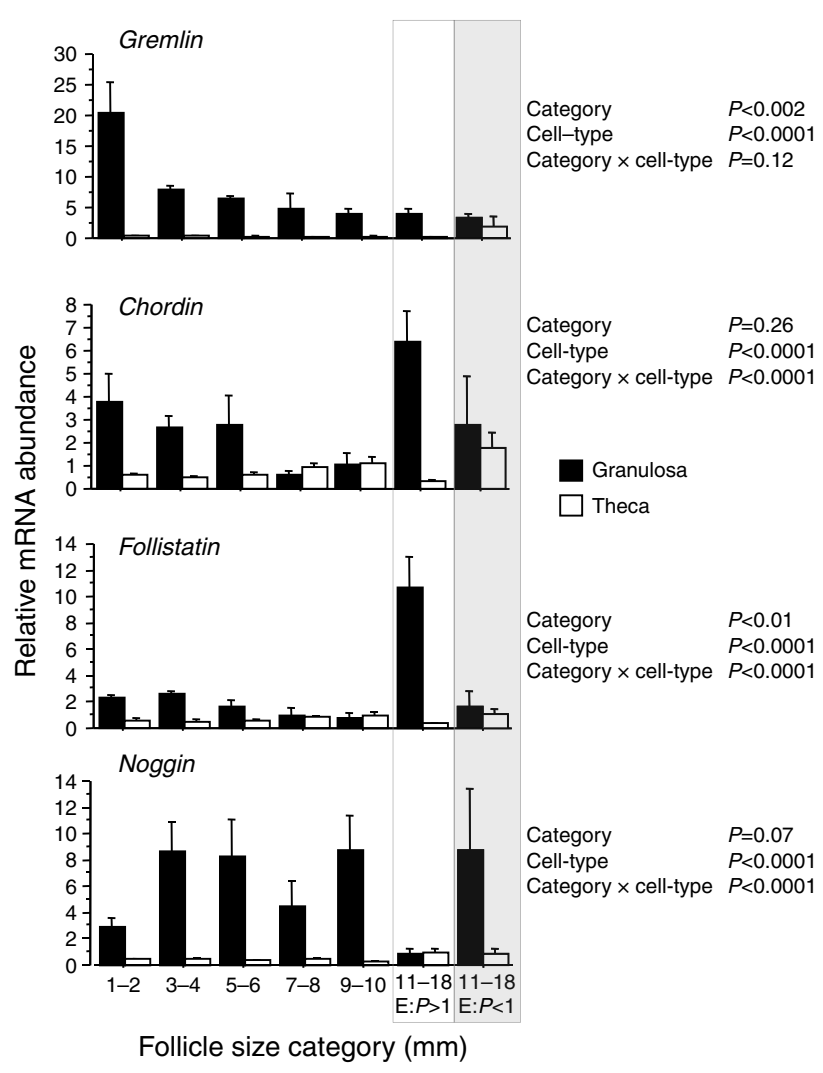

Figure 1 Changes in relative abundance of mRNA transcripts for gremlin, chordin, follistatin and noggin in thecal and granulosal compartments of developing bovine antral follicles. Follicles in the 11-18 mm size class have been subdivided on the basis of oestrogen to progesterone ratio (E:P ratio) as large 'oestrogen-active' (LEA) follicles (E:P ratio $>1$; open box) or large 'oestrogen-inactive' (LEI) follicles (E:P ratio $<1$; shaded box). Values are means and bars indicate S.E.M. $(n=4-9)$. Results of two-way ANOVA are summarised. Note that the same sample set was used in our previous study (Glister et al. 2010) to analyse expression of BMPs, BMP receptors and various follicular 'markers' including LHCGR, FSHR, CYP19 and CYP17.

TC of LEA follicles but was approximately fourfold higher in LEI than in LEA follicles $(P<0.05)$.

Abundance of noggin mRNA was similarly high in GC of all follicle categories with the exception of LEA follicles which showed a approximately tenfold reduction $(P<0.01)$ relative to $9-10 \mathrm{~mm}$ follicles and LEI follicles. Levels of noggin mRNA in TC were much less than in the corresponding GC samples in all follicle categories except LEA follicles when transcript levels were similar in both cell-types.

\section{Correlations amongst expression levels of different transcripts in developing follicles}

Figure 2A shows a correlation matrix listing the pairwise relationships between follicle diameter, $\mathrm{E}_{2}: \mathrm{P}_{4}$ ratio and relative transcript abundance of seven different transcripts in GC. Follicle diameter was positively correlated with $\mathrm{E}_{2}: \mathrm{P}_{4}$ ratio and with GC expression of CYP19, LHCGR and follistatin, but was negatively correlated with gremlin expression. Chordin and follistatin expression in GC were highly correlated $(r=0.73 ; P<0.0001)$ and both were positively correlated with $\mathrm{E}_{2}: \mathrm{P}_{4}$ ratio and with GC expression of FSHR, LHCGR and CYP19. Conversely, GC expression of noggin was negatively correlated with CYP19, LHCGR and follistatin expression.

The corresponding correlation matrix for TC (Fig. 2B) showed fewer significant relationships than observed for GC. However, there were strong positive correlations between CYP17 and LHCGR $(r=0.65 ; P<0.0001)$, between follistatin and chordin $(r=0.59 ; P<0.0001)$ and between noggin and gremlin expression $(r=0.72$; $P<0.0001)$. Conversely, a weak negative correlation was evident between $L H C G R$ and noggin expression in TC $(r=-0.35 ; P<0.05)$.

\section{Immunohistochemical localisation of BPs in ovary sections}

To reinforce the above mRNA expression data ovarian immunohistochemical staining was carried out using antibodies against each of the four BPs. As shown in Fig. 3, immunoreactivity corresponding to all four BPs was evident in follicles. In each case the intensity of staining was much greater in the GC compartment although weak immunoreactivity was also present in TC and stromal compartments.

\section{Effects of FSH and IGF on expression of CYP19, FSHR, INHBA, BMP and BMP-BP transcripts by cultured GC}

Treatment of cultured bovine GC with an optimal dose level of $\mathrm{FSH}(0.33 \mathrm{ng} / \mathrm{ml})$ increased oestradiol $\left(E_{2}\right)$ secretion $\sim 40$-fold $(22.4 \pm 6.7$ vs $0.50 \pm 0.12 \mathrm{ng} / \mathrm{ml}$ in controls; $P<0.001$ ) and promoted a marked upregulation of CYP19 expression $(\sim 35$-fold; $P<0.01)$ that was accompanied by increases in FSHR (approximately fivefold; $P<0.05$ ), follistatin (approximately sixfold; $P<0.01)$ and INHBA $(\sim 11$-fold; $P<0.01)$ mRNA abundance (see Fig. 4). However, FSH did not affect abundance of $B M P 2, B M P 4, B M P 6, B M P 7$, chordin, gremlin or noggin transcripts. Treatment of GC with IGF increased $E_{2}$ secretion approximately sixfold $(3.27 \pm 1.08$ vs 0.50 $\pm 0.12 \mathrm{ng} / \mathrm{ml}$ in controls; $P<0.01$ ) and, as shown in Fig. 4, increased the abundance of transcripts for CYP19 $(\sim 12$-fold; $P<0.05)$ and follistatin (approximately threefold; $P<0.05)$ while decreasing expression of $B M P 4$ (approximately tenfold; $P<0.01$ ), noggin (approximately threefold; $P<0.05$ ) and gremlin (approximately threefold; $P<0.05)$. IGF did not affect the abundance of $F S H R$, INHBA, BMP2, BMP6, BMP7 or chordin mRNA.

\section{Effect of $L H$ on expression of BMP and BMP-BP transcripts by cultured TC}

$\mathrm{LH}$ treatment resulted in a fourfold increase in A4 secretion by cultured TC $(124.1 \pm 26.8$ vs $29.5 \pm 7.0 \mathrm{ng} / \mathrm{ml}$ in 
A

\begin{tabular}{|c|c|c|c|c|c|c|c|c|c|}
\hline Diameter & 1.00 & & & & & & & & \\
\hline $\mathrm{E}: \mathrm{P}$ ratio & $0.50^{\star \star \star}$ & 1.00 & & & & & & & \\
\hline FSHR & 0.16 & $0.36^{\star \star}$ & 1.00 & & & & & & \\
\hline LHCGR & $0.56^{\star \star \star}$ & $0.50^{\star \star \star}$ & $0.37^{* \star}$ & 1.00 & & & & & \\
\hline CYP19 & $0.64^{\star \star \star}$ & $0.52^{\star \star \star}$ & $0.56^{\star \star \star}$ & $0.83^{\star \star \star}$ & 1.00 & & & & \\
\hline Gremlin & $\left(-0.49^{\star \star \star}\right)$ & -0.14 & $0.31^{*}$ & -0.13 & -0.19 & 1.00 & & & \\
\hline Chordin & $0.28^{*}$ & $0.39^{\star \star}$ & $0.57^{\star \star \star}$ & $0.56^{\star \star \star}$ & $0.73^{\star \star \star}$ & 0.11 & 1.00 & & \\
\hline Follistatin & $0.42^{\star \star}$ & $0.47^{\star \star \star}$ & $0.70^{\star \star \star}$ & $0.55^{\star \star \star}$ & $0.81^{\star \star \star}$ & -0.05 & $0.74^{\star \star \star}$ & 1.00 & \\
\hline Noggin & -0.19 & -0.23 & 0.18 & $\left(-0.30^{*}\right)$ & $\left(-0.38^{\star \star}\right)$ & 0.11 & -0.17 & $\left(-0.28^{*}\right)$ & 1.00 \\
\hline
\end{tabular}

B

Diameter

$\mathrm{E}: \mathrm{P}$ ratio

LHCGR

CYP17

Gremlin

Chordin

Follistatin

Noggin

Granulosa layer

Theca interna layer

\begin{tabular}{|c|c|c|c|c|c|c|c|}
\hline \\
\hline 1.00 & & & & & & & \\
\hline $0.41^{* \star}$ & 1.00 & & & & & & \\
\hline$\left(-0.32^{\star}\right)$ & -0.27 & 1.00 & & & & & \\
\hline-0.23 & -0.19 & $0.65^{\star \star \star}$ & 1.00 & & & & \\
\hline 0.17 & -0.05 & -0.15 & -0.17 & 1.00 & & & \\
\hline 0.25 & -0.23 & -0.04 & -0.12 & 0.01 & 1.00 & & \\
\hline 0.13 & -0.13 & 0.10 & -0.03 & -0.05 & $0.59^{\star \star \star}$ & 1.00 & \\
\hline $0.30^{*}$ & 0.27 & $\left(-0.35^{\star}\right)$ & -0.14 & $0.72^{\star \star \star}$ & -0.01 & -0.15 & 1.00 \\
\hline
\end{tabular}

Figure 2 Correlation matrices for $(\mathrm{A})$ granulosal layer and (B) theca interna layer of developing follicles $\left(n=47^{*}\right)$ showing associations between follicle diameter, follicular fluid $E_{2}: P_{4}$ ratio and relative abundance of selected mRNA transcripts including the four BMP/activin-binding proteins. Statistically significant $r$ values are in bold with negative correlations in parenthesis. ${ }^{*} P<0.05,{ }^{* *} P<0.01$ and $* * * P<0.001$. Note that the same sample set was used in our previous study (Glister et al. 2010) to analyse expression of other transcripts including the four follicular 'markers' included in this correlation matrix ( $L H C G R$, FSHR, CYP19 and CYP17). controls; $P<0.01)$ but did not affect the abundance of transcripts for $B M P 2, B M P 4, B M P 6, B M P 7$, chordin, follistatin, noggin or gremlin (data not shown).

\section{Effects of BMPs on expression of steroidogenesis-related transcripts by cultured TC}

Figure 5 shows that treatment of bovine TC with BMP2, BMP4, BMP6 and BMP7 all promoted a profound suppression of CYP17 expression under both basal and LH-stimulated conditions ( $\sim 200$-fold reduction; $P<0.0001)$. Likewise, BMPs reduced expression of other key transcripts involved in the steroidogenic pathway ( $L H C G R, S T A R, C Y P 11 A 1$ and $H S D 3 B$ ) although to much lesser extents than the suppression of $C Y P 17$.

\section{Effects of BMPs on expression of BMP-BP transcripts by cultured TC}

Figure 6 shows that BMP2, BMP4, BMP6 and BMP7 had divergent effects on expression of chordin, noggin and gremlin but did not modify follistatin mRNA abundance. Under both basal and LH-stimulated condition levels of chordin and gremlin mRNA were increased (2- to 11-fold; $P<0.05$ ) by BMP2, BMP4 and BMP6 but not by BMP7. Under LH-stimulated conditions each BMPalso increased the abundance of noggin mRNA with the greatest increase being elicited by BMP6 ( 20-fold: $P<0.01$ ).

\section{Discussion}

This study has provided novel information on the mRNA expression pattern of four different activin/BMP-BPs in granulosal and thecal compartments of developing bovine antral follicles. To our knowledge, such information has not yet been documented for any species. Interestingly, the relative abundance of all four $\mathrm{BP}$ transcripts was greater in GC compared with TC layers throughout antral follicle development. Immunohistochemistry confirmed that the corresponding proteins were also more abundant in GC than TC compartments. In contrast, BMP4, BMP6 and BMP7 transcripts were shown to be more abundant in TC than GC (Glister et al. 2010). We have previously examined the effect of exogenous BMP4, BMP6 and BMP7 on bovine GC and TC cultured in vitro (Glister et al. 2004, 2005) and found TC to be much more sensitive to BMP action $\left(\mathrm{IC}_{50} \sim 1 \mathrm{ng} / \mathrm{ml}\right)$, exhibiting a $>100$-fold decrease in $\mathrm{LH}$-induced androgen secretion at the greatest dose tested $(50 \mathrm{ng} / \mathrm{ml})$, compared with a more modest threefold maximal BMP-induced increase in IGFstimulated oestrogen secretion by GC treated with $50 \mathrm{ng} / \mathrm{ml}$ BMP $\left(\mathrm{EC}_{50} \sim 5 \mathrm{ng} / \mathrm{ml}\right)$. From the present findings, this relative lack of sensitivity of GC versus TC to exogenous BMPs could be explained, at least in part, by the differential expression patterns of BMP-BPs found between the two cell-types - the greater levels of BPs expressed by GC antagonising the signalling activity of exogenous BMPs to a greater extent. Thus, in an in vivo 'whole follicle' context it is conceivable that the GC compartment is relatively resistant to local BMP signalling (BMP4, BMP6 and BMP7 from TC layer; BMP2 mostly from GC layer) due to the presence of higher levels of extracellular BPs. As such, this preliminary evidence supports the concept of BMP signalling gradients across the follicle wall, akin to the morphogen gradients clearly implicated in key aspects of embryonic patterning such as dorsalisation, segmentation and limb bud formation (Thomsen 1997, Balemans \& Van Hul 2002, Chen et al. 2004, Kishigami \& Mishina 2005). 


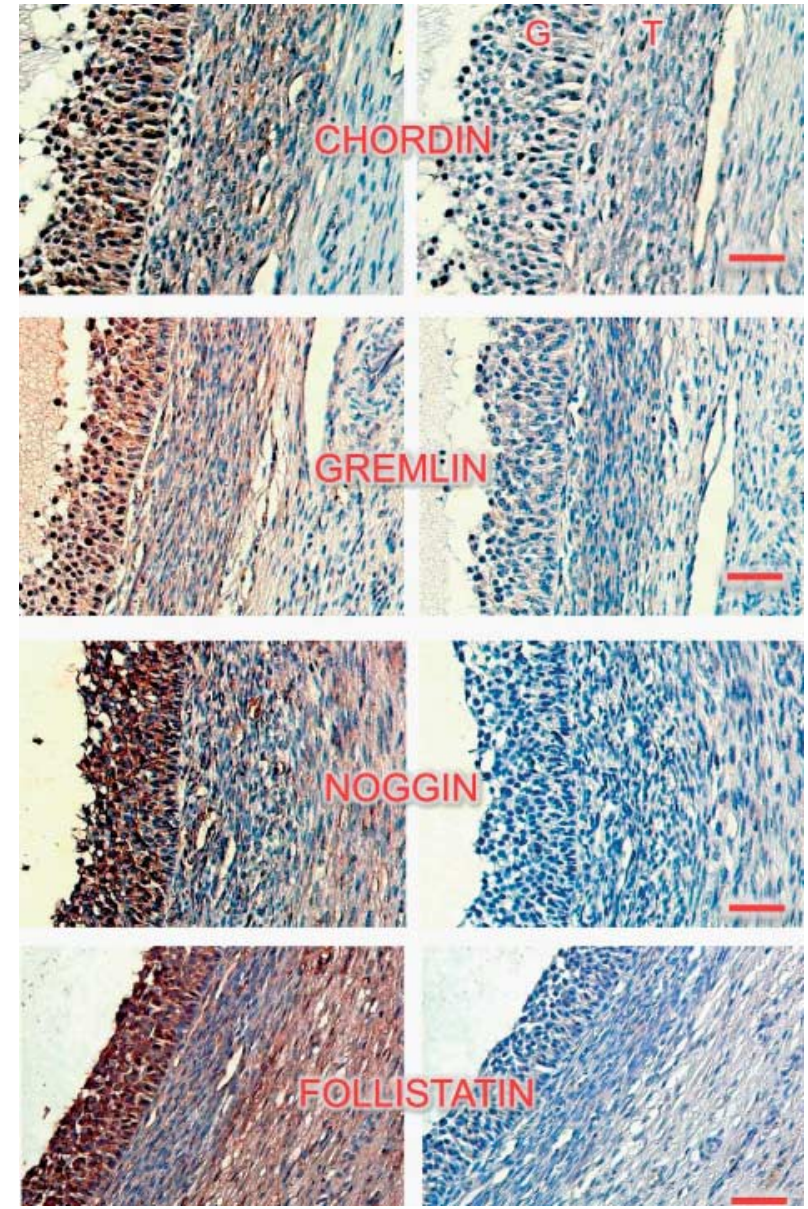

Figure 3 Immunohistochemical staining of bovine ovary sections showing the distribution of chordin, gremlin, noggin and follistatin immunoreactivity (brown) in the granulosa and theca layer of small antral follicles ( $\sim 3$ to $5 \mathrm{~mm}$ diameter). In each panel the left-hand image shows an antibody-treated section while the right-hand image shows an adjacent section treated with the appropriate non-immune serum or purified IgG. The scale bar in each right panel represents $50 \mu \mathrm{m}$.

The finding of differential expression patterns of the four extracellular BPs throughout antral follicle progression suggests selectively regulated expression, as well as different biological roles. For instance, GC expression of follistatin was much greater in LEA than LEI follicles with the inverse seen for noggin. Notably, the previously reported GC expression patterns of INHBA (encoding activin A homodimer) and BMP2 in LEA versus LEI follicles (Glister et al. 2010) mirrored these changes. This supports the notion that activin induces follistatin expression (Tano et al. 1995, Zhang et al. 1997, Silva \& Knight 1998) while BMP2 induces noggin expression (Gazzerro \& Minetti 2007), both acting in an autoregulatory feedback manner to limit signalling by the respective ligands.

Intriguingly, gremlin mRNA level was maximal in GC of the smallest antral follicle stage examined (1-2 mm) and then declined progressively as follicle size increased. In contrast, the other three BPs showed more complex expression patterns but were all relatively low in 1-2 mm follicles. This raises the suggestion that gremlin has a specific role in these small, pre-selection antral follicles. Alternatively, local factors inductive for GC gremlin expression might be more abundant in small antral follicles. In this regard BMP2, BMP4 and GDF9 were found to increase gremlin expression by mouse GC in vitro (Pangas et al. 2004) and this study shows that BMP2, BMP4 and BMP6, but not BMP7, increase gremlin expression by cultured TC. However, as we report elsewhere (Glister et al.2010) expression of BMP2, BMP4 and BMP7 showed little variation in bovine follicles from 1 to $8 \mathrm{~mm}$ in diameter. Moreover, expression of these BMPs by cultured TC and GC was unaffected by $\mathrm{LH}$ and $\mathrm{FSH}$, respectively, even though IGF selectively reduced GC expression of BMP4. Whilst expression of all four BPs was considerably lower in TC than GC, when comparing LEA versus LEI follicles specifically, some differences are apparent in TC. Gremlin, chordin and follistatin were more highly expressed in the TC of LEI follicles compared with LEA, whilst noggin remained unchanged. This might imply a role in neutralising factors involved in maintenance of the dominant follicle, a proposal that should be amenable to in vitro testing using an RNAi 'knockdown' approach.

To extend the above findings of spatiotemporal changes in follicular BMP-BP expression during antral follicle development, we conducted in vitro studies on isolated GC and TC to ascertain whether key trophic factors influenced expression of any of the four BPs, along with several key GC or TC markers. As anticipated, and consistent with other studies (Campbell et al. 1996, Gutierrez et al. 1997, Glister et al. 2001, Marsters et al. 2003), treatment of GC with FSH enhanced $E_{2}$ secretion and promoted expression of CYP19, its own receptor (FSHR) and INHBA (encoding activin A subunit), while IGF raised $E_{2}$ secretion and CYP19 without effecting FSHR or INHBA expression. Follistatin mRNA expression was also raised by both treatments, consistent with previous follistatin secretion data for FSH and IGFtreated bovine GC (Glister et al. 2001, 2003, 2006) and with findings in other species (see Findlay 1993). However, FSH had no effect on expression of the four BMPs examined or their antagonists - chordin, noggin and gremlin. Previously, in vivo PMSG treatment in mice was found to increase GC gremlin expression (Pangas et al. 2004). In contrast to the lack of effect of FSH on GC, treatment with IGF selectively reduced GC expression of BMP4, noggin and gremlin perhaps indicating a functional link between BMP4 and these two BPs.

As anticipated, treatment of cultured TC with their key trophic factor, LH, promoted a significant (sixfold) increase in androgen secretion. However, LH had no discernable effect on expression levels of any of the four BMPs or BPs analysed. Therefore, we infer that expression of BMPs and BMP-BPs by GC and TC from antral follicles is largely unaffected by gonadotrophin 


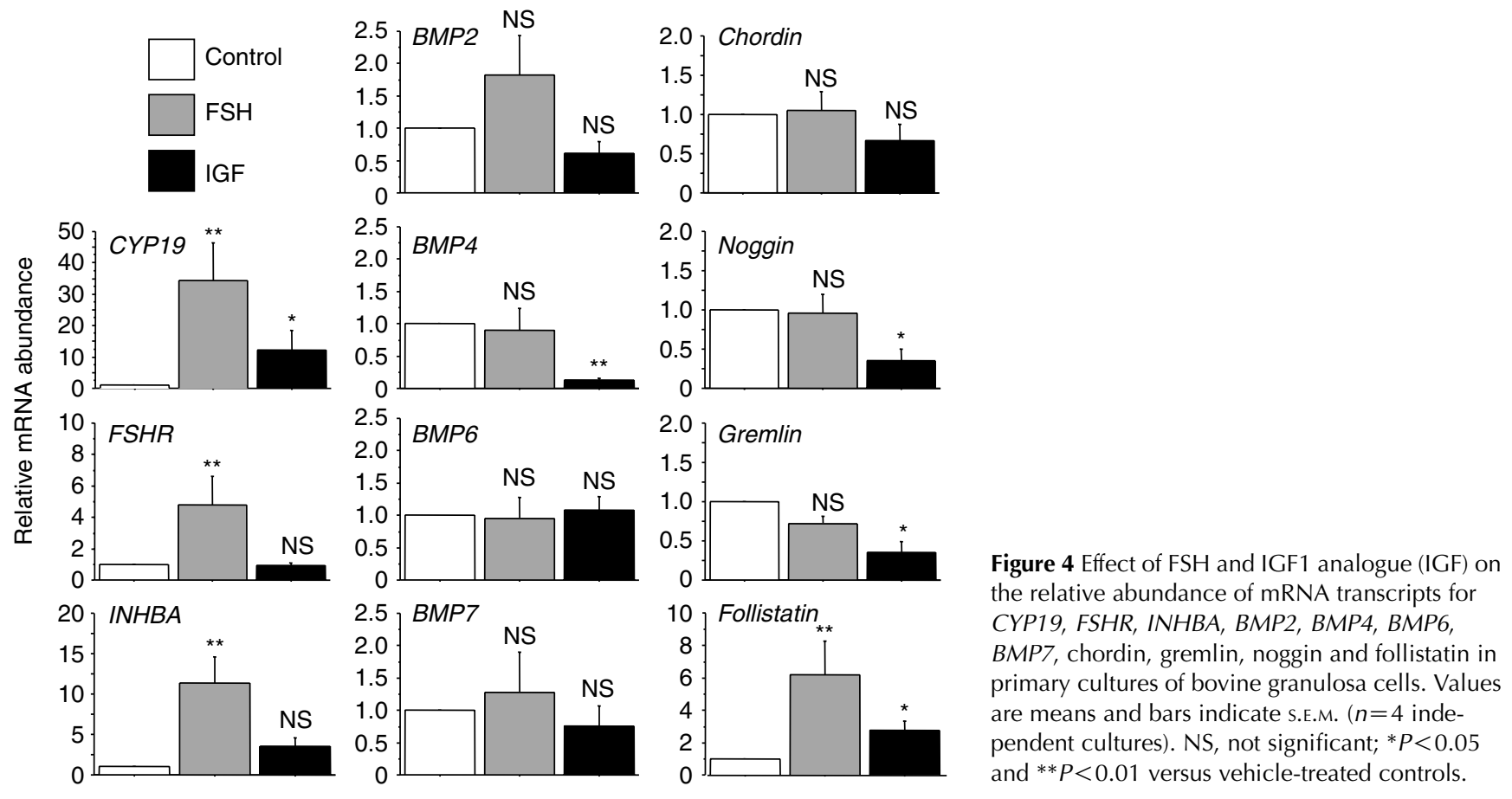

stimulation, at least under the defined culture conditions used for this study. Further studies would be useful to ascertain whether gonadotrophins and other factors modulate TC/GC expression of BMP-BPs at other follicle stages, including preantral and luteinisation stages in cattle, and indeed other species.

Given the high responsiveness of cultured bovine TC to exogenous BMPs in terms of suppression of androgen secretion (Glister et al. 2005), we reasoned that this would be a robust model to investigate whether the different BMPs also modulated expression of any of the four extracellular BPs. We first confirmed that BMP2, BMP4, BMP6 and BMP7 drastically reduced expression of the key enzyme involved in androgen biosynthesis CYP17 (>100-fold), with lesser effects on other components of the thecal steroidogenic pathway, including LHCGR (approximately sixfold), STAR (approximately twofold), CYP11A (approximately

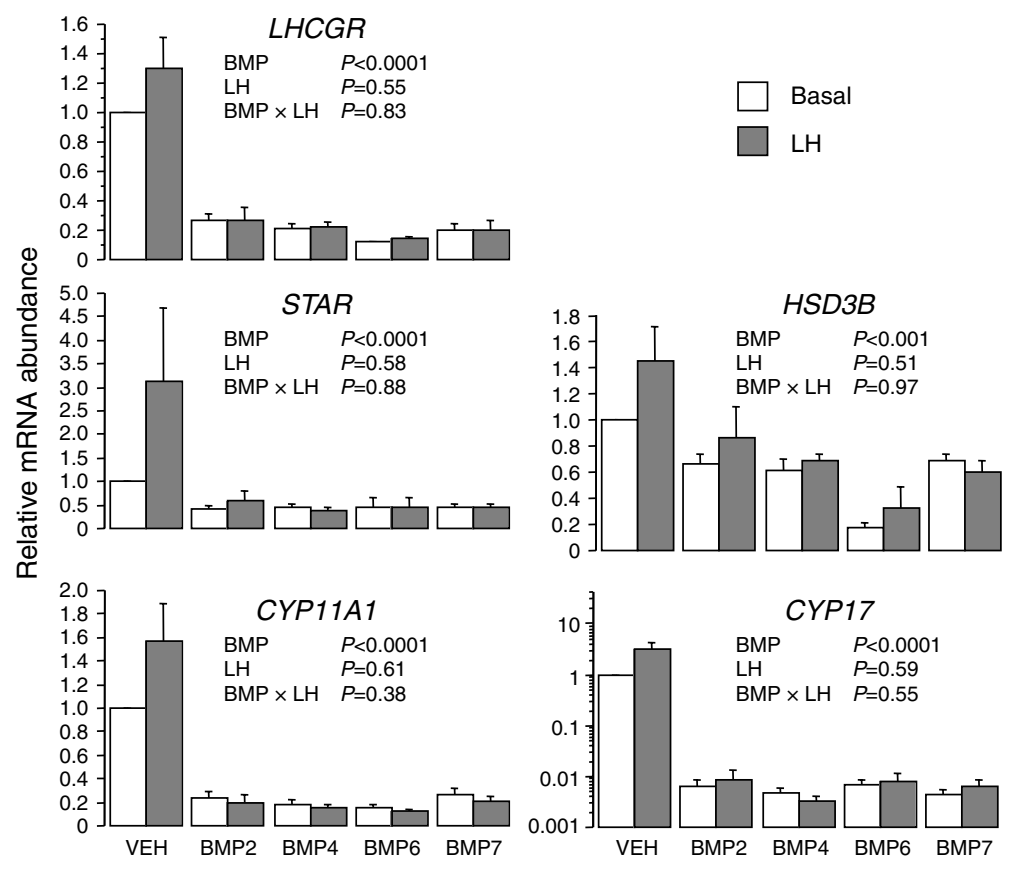

Figure 5 Effects of BMP2, BMP4, BMP6 and BMP7, alone and in combination with $\mathrm{LH}$, on the relative abundance of five key steroidogenic mRNA transcripts ( $L H C G R$, STAR, CYP11A1, HSD3B and CYP17) in primary cultures of bovine theca interna cells. Values are means and bars indicate S.E.M. ( $n=4$ independent cultures). Results of two-way ANOVA are summarised. 

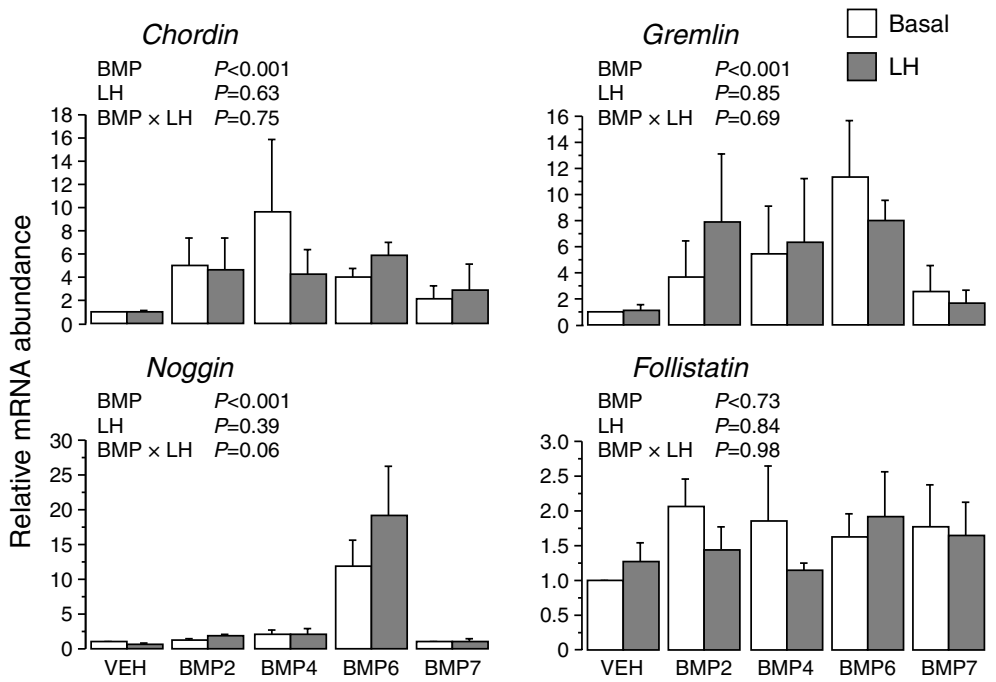

Figure 6 Effects of BMP2, BMP4, BMP6 and BMP7, alone and in combination with $\mathrm{LH}$, on the relative abundance of mRNA transcripts for chordin, gremlin, noggin and follistatin in primary cultures of bovine theca interna cells. Values are means and bars indicate s.E.M. ( $n=4$ independent cultures). Results of two-way ANOVA are summarised.

sixfold) and HSD3B (approximately twofold). Whilst all four BMPs caused a modest increase in expression of chordin and gremlin, (independent of LH treatment) only one, BMP6, promoted a marked (greater than tenfold) increase in noggin expression. None of the four BMPs tested altered follistatin expression by TC, a finding at variance with previous observations in bovine GC that show a clear BMP-induced upregulation of follistatin secretion (Glister et al. 2004).

Previous studies on various cell-types have reported the ability of BMPs to induce expression of their own antagonists. For instance, BMP2, BMP4 and BMP6 have each been shown to induce noggin expression by osteoblasts, at the mRNA and protein level (Gazzerro \& Minetti 2007) even though noggin appears to bind to BMP2 and BMP4 with much greater affinity than to BMP6 (Pierre et al. 2005). Interestingly, the present data indicate that, of the four ligands we tested, only BMP6 has the ability to induce noggin expression by bovine TC. In a similar manner BMP2 and BMP4, which are antagonised by gremlin, have been shown to induce gremlin expression by mouse GC (Pangas et al. 2004) and rat osteoblasts (Pereira et al. 2000). In agreement, we report here that BMP2 and BMP4 can also increase gremlin expression by bovine TC in vitro. BMP6 was similarly effective at promoting gremlin expression whereas BMP7 had little or no effect. Chordin expression has previously been reported to be non-inducible by BMPs (Canalis et al. 2003), despite binding directly to and inhibiting BMP2, BMP4 and BMP7. However, in our study chordin expression was raised by all four BMPs tested. Previously, BMPs were shown to enhance secretion of follistatin by both non-luteinised (Glister et al. 2004) and luteinised (Kayani et al. 2009) bovine GC. In contrast, this study found no effect of BMPs on TC expression of follistatin mRNA. Since the binding affinity of follistatin for activin is much greater than that for BMPs (Otsuka et al. 2001, Amthor et al. 2002, Glister et al.
2004) it would be anticipated that activin is a more effective inducer of follistatin expression and, indeed, activin-induced follistatin expression has been documented for various cell-types including rat GC (Tano et al. 1995), hepatocytes (Zhang et al. 1997) and bovine cumulus-oocyte complexes (Silva \& Knight 1998), but not human granulosa-lutein cells (Tuuri \& Ritovs 1995).

Apparent differences in the ability of individual BMPs to modulate expression of different BPs, evident from the studies referred to above, can partially be attributed to the different cell-types and species under investigation, and to differences in experimental design and culture conditions. Taken together, however, it is increasingly evident that local autoregulatory loops operate at the target tissue/cell level with BMPs capable of inducing expression of their own extracellular antagonists. In turn, these act primarily as 'ligand traps' to sequester BMPs and limit their signalling range by blocking interaction with signalling receptors (Reddi 2001, Gazzerro \& Canalis 2006, Walsh et al. 2010).

Whilst it is well established that follistatin has an intraovarian role in antagonising the effects of activin on TC, GC, luteal cells and oocytes (reviews: Findlay 1993, Welt et al. 2002, Knight \& Glister 2006) what evidence is there to support a functional role of BMP-BPs in the modulation of follicular function? Noggin has been shown to block the suppressive effect of BMP2 and BMP4, but not BMP6, on progesterone secretion by sheep GC in vitro (Pierre et al. 2004). Likewise, gremlin and gremlin 2 (aka PRDC; protein related to DAN and cerberus) reversed the BMP2/BMP4-induced suppression of progesterone secretion by rat GC (Sudo et al. 2004). Gremlin and chordin also antagonised the suppressive action of BMP4 and BMP7, respectively, on androgen secretion by bovine TC in vitro (Glister et al. 2005). Moreover, in the absence of BMP treatments, both BPs promoted TC androgen secretion 
indicating that endogenous BMPs negatively regulate androgen production in an autocrine/paracrine manner.

Given the marked inhibitory effect of activins and BMPs on thecal androgen production, it has also been suggested (Glister et al. 2005) that compromised intraovarian activin and/or BMP signalling, perhaps due to overexpression or activity of extracellular BPs could by a contributory factor in polycystic ovarian syndrome (PCOS), a condition associated with ovarian androgen excess and impaired preovulatory follicle development (Mason 2000). Consistent with this notion, there have been several reports of raised circulating follistatin levels in women with PCOS (Norman et al. 2001, Chen et al. 2009). However, we are not aware of any evidence implicating altered expression of other extracellular BMP-BPs in the aetiology of PCOS.

In summary, this study has revealed that four different secreted BMP/activin-BPs (gremlin, noggin, chordin and follistatin) show divergent expression patterns in GC and TC compartments during bovine antral follicle development. With the exception of $\mathrm{FSH}$-induced follistatin expression by GC, gonadotrophins do not appear to modulate GC and TC expression of either BMPs or BMPBPs. In contrast, IGF induces follistatin expression whilst suppressing BMP4, noggin and gremlin expression by GC. In addition, we have shown that treatment of TC with BMPs can differentially regulate expression of their own BPs, consistent with the notion of local autoregulatory feedback loop(s) controlling BMP signalling. Taken together, these findings support the hypothesis that extracellular BPs play important roles in regulating BMP signalling in ovarian follicles. Further studies are needed to delineate the relative contributions of individual intraovarian BMP ligands and BPs in this complex and dynamic organ.

\section{Materials and Methods}

Unless stated otherwise, all media and reagents were purchased from Sigma UK Ltd or Fisher Scientific Ltd (Loughborough, UK).

\section{Ovaries and isolation of $G C$ and TC for gene expression analysis}

As described in our recent companion paper (Glister et al. 2010) ovaries from non-pregnant cattle slaughtered at random stages of the oestrous cycle were collected from an abattoir and oestrous cycle stage (I-IV) was estimated by morphological appearance of the corpus luteum (Ireland et al. 1980). Only ovaries judged to be from cattle in the mid- to late-luteal phase (stages II and III; days 5-17) were selected for follicle dissection. Follicles ranging in diameter from 1 to $18 \mathrm{~mm}$ were dissected out, sorted by size and their GC, TC layers and follicular fluid recovered for analysis. Individual follicles in the 1-2 mm (ten follicles per pool, $n=6$ pools collected, $n=4$ pools analysed), 3-4 mm (six follicles per pool; $n=7$ pools collected, $n=5$ pools analysed) and 5 $-6 \mathrm{~mm}$ (six follicles per pool; $n=6$ pools collected, $n=5$ pools analysed) size categories were combined for further analysis while all follicles $>7 \mathrm{~mm}$ in diameter were processed and analysed individually ( $n=7-9$ per category). The number of follicle samples included in the analysis was lower than the number collected because only $80 \%$ of samples passed our quality control criteria based on comparison of GC/TC-specific 'marker' transcript levels (see Glister et al. (2010) for further details). Isolated GC and TC were homogenised in $0.5 \mathrm{ml}$ of Tri-reagent (Sigma UK Ltd) and stored at $-80{ }^{\circ} \mathrm{C}$ for subsequent RNA purification. The size range of antral follicles investigated spanned key points in bovine follicular development, including 'cyclic recruitment' at $3-5 \mathrm{~mm}$, selection/deviation at $\sim 6$ to $8 \mathrm{~mm}$, LHCGR acquisition by GC at $9-10 \mathrm{~mm}$ and dominance at $11-18 \mathrm{~mm}$ (Ireland et al. 2000, Mihm \& Austin 2002, Ginther et al. 2003). The final follicle size category was further subdivided based on follicular fluid E:P ratio reflecting presumptive healthy, LEA dominant follicles (E:P ratio $>1$ ) and LEl, most likely undergoing regression $(\mathrm{E}: \mathrm{P}$ ratio $<1)$.

\section{GC and TC culture}

For in vitro experiments, GC and TC layers pooled from $\sim 50$ follicles (4-6 $\mathrm{mm}$ diameter) per culture were collected as above and further processed as described by Glister et al. (2005) to obtain individual cell suspensions. The serum-free culture medium used was McCoy's 5A supplemented with $1 \%(\mathrm{v} / \mathrm{v})$ antibiotic-antimycotic solution, $10 \mathrm{ng} / \mathrm{ml}$ insulin (bovine pancreas), $2 \mathrm{mM}$ L-glutamine, $10 \mathrm{mM}$ HEPES, $5 \mu \mathrm{g} / \mathrm{ml}$ apotransferrin, $5 \mathrm{ng} / \mathrm{ml}$ sodium selenite and $0.1 \%(\mathrm{w} / \mathrm{v})$ BSA. For GC cultures medium was supplemented with androstenedione $\left(10^{-7} \mathrm{M}\right)$. Cells were plated at 75000 viable cells/well in 96-well plates (Nunclon, Life Technologies Ltd) and cultured for 6 days at $38.5^{\circ} \mathrm{C}$. Media were removed every $48 \mathrm{~h}$ and replaced with fresh media containing treatments (see below). Conditioned media were stored at $-20{ }^{\circ} \mathrm{C}$ for steroid immunoassays. At the end of culture viable cell number was determined using neutral red assay (Campbell et al. 1996, Glister et al. 2001).

\section{RNA isolation from cultured cells}

In culture experiments in which total RNA was to be extracted for qRT-PCR analysis, cells were seeded into 24-well plates $\left(0.5 \times 10^{6}\right.$ cells $\left./ \mathrm{ml}\right)$ with three replicate wells per treatment. At the end of culture lysates were prepared using Tri-reagent and pooled lysates from replicate wells stored at $-80{ }^{\circ} \mathrm{C}$.

\section{Culture treatments}

Ovine FSH (oFSH-19SIAPP) and LH (oLH-S-16) were provided by the NHPP (Torrance, CA, USA), LR3-IGF-1 was purchased from Sigma and recombinant human (rh) BMP2, BMP4, BMP6 and BMP7 were purchased from R\&D Systems (Abingdon, UK). Treatments were sterilised using $0.2 \mu \mathrm{m}$ filters before further dilution in sterile culture medium. Treatments were added at $25 \mu \mathrm{l} /$ well and an equal volume of blank medium added to control wells. 


\section{Steroid assays}

Concentrations of $\mathrm{P}_{4}$ were determined by ELISA (Sauer et al. 1986, Bleach et al. 2001). The detection limit was $20 \mathrm{pg} / \mathrm{ml}$ and intra- and inter-assay coefficient of variation (CV) were 8 and $10 \%$ respectively. Concentrations of $E_{2}$ were determined by RIA (Tannetta et al. 1997) with a detection limit of $2 \mathrm{pg} / \mathrm{ml}$ and intraand inter-assay CV of 6 and $9 \%$ respectively. Concentrations of A4 were determined by RIA (Tannetta et al. 1997) with a detection limit of $100 \mathrm{pg} / \mathrm{ml}$ and intra- and inter-assay CV of 7 and $10 \%$ respectively.

\section{RNA isolation, cDNA synthesis and real-time PCR}

Total RNA was isolated from tissue samples and cultured cells using Tri-reagent as described previously (Glister et al. 2010). Potential genomic DNA contamination was removed with an RNase-free DNase kit (RQ1; Promega UK Ltd). RNA quantity and quality were evaluated by spectrophotometry at 260/ $280 \mathrm{~nm}$. cDNA was synthesised from $1 \mu \mathrm{g}$ of RNA using the Reverse-iT RT kit (Abgene, Epsom, UK; used according to manufacturer's protocol) in a $20 \mu \mathrm{l}$ reaction primed with random hexamers.

Primers (see Table 1) were designed using ABI PRISM primer express software (version 1.5; Perkin Elmer-Applied Biosystems, Warrington, UK) and validated using melt-curve analysis and agarose gel electrophoresis to verify that each primer pair generated a single amplicon of the predicted size. cDNA template log-dilution curves were used to demonstrate satisfactory PCR efficiency and linearity. PCR assays were carried out in a volume of $24 \mu \mathrm{l}$, comprising $10 \mu \mathrm{l}$ cDNA template (equivalent to $\sim 20$ ng reverse-transcribed RNA), $1 \mu$ l each forward and reverse primers (final concentration $0.4 \mu \mathrm{M}$ ) and $12 \mu \mathrm{l}$ QuantiTect SYBR Green QPCR $2 \times$ Master Mix (Qiagen). Samples were processed on an ABI PRISM 7700 thermal cycler (Perkin Elmer-Applied Biosystems) with cycling conditions: $15 \mathrm{~min}$ at $95{ }^{\circ} \mathrm{C}$ (one cycle only) followed by $15 \mathrm{~s}$ at $95^{\circ} \mathrm{C}$ and $1 \mathrm{~min}$ at $60{ }^{\circ} \mathrm{C}$ for 40 cycles.

The $\Delta \Delta C_{\mathrm{t}}$ method (Livak \& Schmittgen 2001) was used to compare the relative abundance of each mRNA transcript. $C_{\mathrm{t}}$ values for each transcript in a given sample were first normalised to $\beta$-actin $C_{\mathrm{t}}$ value (uniform across experimental all groups: ANOVA $P>0.2$ ). For cell culture experiments the resultant $\Delta C_{\mathrm{t}}$ values for each treatment replicate were then normalised to the mean $\Delta C_{\mathrm{t}}$ value of the respective vehicletreated control group. For tissue samples (GC and TC) $\Delta C_{t}$ values for each transcript in a given sample were normalised to the mean $\Delta C_{\mathrm{t}}$ value for that transcript in all tissue samples. For graphical presentation $\Delta \Delta C_{\mathrm{t}}$ values were converted to folddifferences using the formula: fold-difference $=2^{\left(-\Delta \Delta C_{\mathrm{t}}\right)}$.

\section{Immunohistochemistry}

Immunohistochemical staining was performed on $6 \mu \mathrm{m}$ sections of formalin-fixed, paraffin-embedded ovaries as described previously (Glister et al. 2010). Ovaries from four cattle were processed and each antibody was used to stain at least two sections from each of four different ovaries. After microwave antigen retrieval using citrate buffer $(10 \mathrm{mM}, \mathrm{pH}$ 6), sections were blocked for $1 \mathrm{~h}$ using either $2.5 \%(\mathrm{v} / \mathrm{v})$ horse serum (supplied with anti-mouse/rabbit ImmPRESS Kit, Vector Laboratories, Peterborough, UK) or $10 \%(\mathrm{v} / \mathrm{v})$ bovine serum (used with biotinylated anti-goat IgG and Vectastain ABC Elite kit; Vector Laboratories). The following primary antibodies (and appropriately matched control serum/purified IgG for adjacent tissue section) were diluted in blocking buffer and incubated with sections overnight at $4{ }^{\circ} \mathrm{C}$ : goat anti-mouse gremlin (R\&D Systems) at $5 \mu \mathrm{g} / \mathrm{ml}$, goat anti-mouse chordin (R\&D Systems) at $5 \mu \mathrm{g} / \mathrm{ml}$, rabbit anti-human noggin (Abcam Ltd, Cambridge, UK) at $5 \mu \mathrm{g} / \mathrm{ml}$ and rabbit anti-human follistatin (FP22; supplied by NIDDK, Baltimore, MD, USA) at 1:500 dilution. For immunodetection of rabbit primary antibodies, the ImmPRESS Universal anti-mouse/rabbit IgG HRP polymerbased detection system was used with diaminobenzidine substrate according to the manufacturer's instructions. For immunodetection of goat primary antibodies, sections were incubated for $30 \mathrm{~min}$ with biotinylated bovine anti-goat IgG ( $5 \mu \mathrm{g} / \mathrm{ml}$; Santa Cruz, Insight Biotechnology, Wembley, UK) before labelling with avidin-biotin HRP complex and diaminobenzidine substrate according to the supplier's protocol. Slides were counterstained with haematoxylin, dehydrated and

Table 1 List of primers used for quantitative RT-PCR.

\begin{tabular}{|c|c|c|c|c|}
\hline Target & Accession number & Forward primer $5^{\prime}-3^{\prime}$ & Reverse primer $5^{\prime}-3^{\prime}$ & $\begin{array}{l}\text { Amplicon } \\
\text { size (bp) }\end{array}$ \\
\hline FSHR & NM_174061.1 & GCCAGCСТСАССТАССССАGC & AATTGGATGAAGGTCAGAGGTTTGCC & 75 \\
\hline LHCGR & NM_174381.1 & ATTGCCTCAGTCGATGCCCAGACC & AAAAAGCCAGCCGCGCTGC & 92 \\
\hline STAR & NM_174189 & TTTTTTCCTGGGTCCTGACAGCGTC & ACAACCTGATCCTTGGGTTCTGCACC & 103 \\
\hline CYP11A1 & NM_176644 & САGTGTCССТСТGСТСАAСGTCC & TTATTGAAAATTGTGTCCCATGCGG & 99 \\
\hline$H S D 3 B$ & NM_174343.2 & GCCACСTAGTGACTСТTTCCAACAGCG & TGGTTTTCTGCTTGGCTTCСTCCC & 111 \\
\hline CYP17 & NM_174304 & GACAAAGGCACAGACGTTGTGGTCA & TGATCTGCAAGACGAGACTGGCATG & 301 \\
\hline CYP19 & NM_174305.1 & CGCCACTGAGTTGATTTTTGCTGAGA & TAAGGCTTTGCGCATGACCAGGTC & 301 \\
\hline BMP2 & XM_866011.1 & CCAAGAGGCATGTGCGGATTAGCA & TCCTTTCCCATCGTGGCCAAAAGT & 101 \\
\hline$B M P 4$ & NM_001045877.1 & TTTATGAGGTTATGAAGCCCCCGGC & AGTTTCCCACCGCGTCACATTGTG & 104 \\
\hline BMP6 & XM_600972.2 & GGCCCCGTTAACTCGACTGTGACAAA & TTGAGGACGCCGAACAAAACAGGA & 108 \\
\hline BMP7 & XM_612246.2 & TGCAAGATAGCCACTTCCTCACCGA & GGGATCTTGGAGAGATCAAACCGGA & 130 \\
\hline Chordin & XM_001788437.1 & ССТАСССGААTССGСТTСТСТGАСТСС & GACAACCGAGGCACTGCCCGC & 113 \\
\hline Gremlin & NM_001082450.1 & GAAGCGAGACTGGTGCAAAACCCA & TATGCAACGGCACTGCTTGACACG & 271 \\
\hline Noggin & XM_582573.4 & CAAGAAGCAGCGCCTGAGCAAGA & GAAACAGCTGCCCACСTTCACGTAG & 142 \\
\hline Follistatin & NM_175801.2 & TGAGCAAGGAGGAGTGTTGCAGCA & CATCTGGCCTTGAGGAGTGCACATTC & 301 \\
\hline ACTB & NM_173979.3 & ATCACCATCGGCAATGAGCGGTTC & CGGATGTCGACGTCACACTTCATGA & 128 \\
\hline
\end{tabular}


mounted under glass cover slips. Sections were viewed on a Zeiss Axioskop 2 microscope $(20 \times$ objective) and images acquired using a Zeiss Axiocam with Axiovision software.

\section{Statistical analysis}

To reduce heterogeneity of variance immunoassay data were log-transformed before statistical analysis and QPCR data were analysed as $\Delta C_{\mathrm{t}}$ values before conversion to fold-difference values. Results were evaluated using one- and/or two-way ANOVA and, where indicated, post hoc comparisons made by Fisher's protected least significant difference (PLSD) test. Post hoc tests were only made when ANOVA yielded a significant F-ratio. In vitro results presented are based on combined data from four independent culture experiments.

\section{Declaration of interest}

The authors declare that there is no conflict of interest that could be perceived as prejudicing the impartiality of the research reported.

\section{Funding}

This work was supported by the Biotechnology and Biological Sciences Research Council (grants BBS/B/10439 and BB/G017174/1 to P G Knight).

\section{References}

Amthor H, Christ B, Rashid-Doubell F, Kemp CF, Lang E \& Patel K 2002 Follistatin regulates bone morphogenetic protein-7 (BMP-7) activity to stimulate embryonic muscle growth. Developmental Biology 243 115-127. (doi:10.1006/dbio.2001.0555)

Avsian-Kretchmer O \& Hsueh AJ 2004 Comparative genomic analysis of the eight-membered ring cystine knot-containing bone morphogenetic protein antagonists. Molecular Endocrinology 18 1-12. (doi:10.1210/ me.2003-0227)

Balemans W \& Van Hul W 2002 Extracellular regulation of BMP signaling in vertebrates: a cocktail of modulators. Developmental Biology 250 231-250. (doi:10.1006/dbio.2002.0779)

Bleach EC, Glencross RG, Feist SA, Groome NP \& Knight PG 2001 Plasma inhibin A in heifers: relationship with follicle dynamics, gonadotrophins, and steroids during the estrous cycle and after treatment with bovine follicular fluid. Biology of Reproduction 64 743-752. (doi:10.1095/ biolreprod64.3.743)

Campbell BK, Scaramuzzi RJ \& Webb R 1996 Induction and maintenance of oestradiol and immunoreactive inhibin production with FSH by ovine granulosa cells cultured in serum-free media. Journal of Reproduction and Fertility 106 7-16. (doi:10.1530/jrf.0.1060007)

Canalis E, Economides AN \& Gazzerro E 2003 Bone morphogenetic proteins, their antagonists, and the skeleton. Endocrine Reviews $\mathbf{2 4}$ 218-235. (doi:10.1210/er.2002-0023)

Chen D, Zhao M \& Mundy GR 2004 Bone morphogenetic proteins. Growth Factors 22 233-241. (doi:10.1080/08977190412331279890)

Chen MJ, Chen HF, Chen SU, Ho HN, Yang YS \& Yang WS 2009 The relationship between follistatin and chronic low-grade inflammation in women with polycystic ovary syndrome. Fertility and Sterility 92 2041-2044. (doi:10.1016/j.fertnstert.2009.06.009)

Findlay JK 1993 An update on the roles of inhibin, activin, and follistatin as local regulators of folliculogenesis. Biology of Reproduction 48 15-23. (doi:10.1095/biolreprod48.1.15)
Gazzerro E \& Canalis E 2006 Bone morphogenetic proteins and their antagonists. Reviews in Endocrine \& Metabolic Disorders 7 51-65. (doi:10.1007/s11154-006-9000-6)

Gazzerro E \& Minetti C 2007 Potential drug targets within bone morphogenetic protein signaling pathways. Current Opinion in Pharmacology 7 325-333. (doi:10.1016/j.coph.2007.01.003)

Ginther OJ, Beg MA, Donadeu FX \& Bergfelt DR 2003 Mechanism of follicle deviation in monovular farm species. Animal Reproduction Science 78 239-257. (doi:10.1016/S0378-4320(03)00093-9)

Glister C, Tannetta DS, Groome NP \& Knight PG 2001 Interactions between follicle-stimulating hormone and growth factors in modulating secretion of steroids and inhibin-related peptides by nonluteinized bovine granulosa cells. Biology of Reproduction 65 1020-1028. (doi:10. 1095/biolreprod65.4.1020)

Glister C, Groome NP \& Knight PG 2003 Oocyte-mediated suppression of follicle-stimulating hormone- and insulin-like growth factor-induced secretion of steroids and inhibin-related proteins by bovine granulosa cells in vitro: possible role of transforming growth factor alpha. Biology of Reproduction 68 758-765. (doi:10.1095/biolreprod.102.008698)

Glister C, Kemp CF \& Knight PG 2004 Bone morphogenetic protein (BMP) ligands and receptors in bovine ovarian follicle cells: actions of BMP-4, -6 and -7 on granulosa cells and differential modulation of Smad- 1 phosphorylation by follistatin. Reproduction 127 239-254. (doi:10. 1530/rep.1.00090)

Glister C, Richards SL \& Knight PG 2005 Bone morphogenetic proteins (BMP) $-4,-6$, and -7 potently suppress basal and luteinizing hormoneinduced androgen production by bovine theca interna cells in primary culture: could ovarian hyperandrogenic dysfunction be caused by a defect in thecal BMP signaling? Endocrinology 146 1883-1892. (doi:10. 1210/en.2004-1303)

Glister C, Groome NP \& Knight PG 2006 Bovine follicle development is associated with divergent changes in activin-A, inhibin-A and follistatin and the relative abundance of different follistatin isoforms in follicular fluid. Journal of Endocrinology 188 215-225. (doi:10.1677/joe.1.06485)

Glister C, Satchell L \& Knight PG 2010 Changes in expression of bone morphogenetic proteins (BMPs), their receptors and inhibin co-receptor betaglycan during bovine antral follicle development: inhibin can antagonize the suppressive effect of BMPs on thecal androgen production. Reproduction 140 699-712. (doi:10.1530/REP-10-0216)

Gutierrez CG, Campbell BK \& Webb R 1997 Development of a long-term bovine granulosa cell culture system: induction and maintenance of estradiol production, response to follicle-stimulating hormone, and morphological characteristics. Biology of Reproduction 56 608-616. (doi:10.1095/biolreprod56.3.608)

Hsu DR, Economides AN, Wang X, Eimon PM \& Harland RM 1998 The Xenopus dorsalizing factor Gremlin identifies a novel family of secreted proteins that antagonize BMP activities. Molecular Cell 1 673-683. (doi:10.1016/S1097-2765(00)80067-2)

Ireland JJ, Murphee RL \& Coulson PB 1980 Accuracy of predicting stages of bovine estrous cycle by gross appearance of the corpus luteum. Journal of Dairy Science 63 155-160. (doi:10.3168/jds.S0022-0302 (80)82901-8)

Ireland JJ, Mihm M, Austin E, Diskin MG \& Roche JF 2000 Historical perspective of turnover of dominant follicles during the bovine estrous cycle: key concepts, studies, advancements, and terms. Journal of Dairy Science 83 1648-1658. (doi:10.3168/jds.S0022-0302(00)75033-8)

Jasuja R, Allen BL, Pappano WN, Rapraeger AC \& Greenspan DS 2004 Cell-surface heparan sulfate proteoglycans potentiate chordin antagonism of bone morphogenetic protein signaling and are necessary for cellular uptake of chordin. Journal of Biological Chemistry 279 51289-51297. (doi:10.1074/jbc.M408129200)

Juengel JL \& McNatty KP 2005 The role of proteins of the transforming growth factor-beta superfamily in the intraovarian regulation of follicular development. Human Reproduction Update 11 143-160. (doi:10.1093/ humupd/dmh061)

Kameda T, Koike C, Saitoh K, Kuroiwa A \& Iba H 1999 Developmental patterning in chondrocytic cultures by morphogenic gradients: BMP induces expression of Indian hedgehog and noggin. Genes to Cells $\mathbf{4}$ 175-184. (doi:10.1046/j.1365-2443.1999.00250.x)

Kayani AR, Glister C \& Knight PG 2009 Evidence for an inhibitory role of bone morphogenetic protein(s) in the follicular-luteal transition in cattle. Reproduction 137 67-78. (doi:10.1530/REP-08-0198) 
Khokha MK, Hsu D, Brunet LJ, Dionne MS \& Harland RM 2003 Gremlin is the BMPantagonist required for maintenance of Shh and Fgf signals during limb patterning. Nature Genetics 34 303-307. (doi:10.1038/ng1178)

Kishigami S \& Mishina Y 2005 BMP signaling and early embryonic patterning. Cytokine \& Growth Factor Reviews 16 265-278. (doi:10. 1016/j.cytogfr.2005.04.002)

Knight PG \& Glister C 2006 TGF-beta superfamily members and ovarian follicle development. Reproduction 132 191-206. (doi:10.1530/rep.1.01074)

Lamb TM, Knecht AK, Smith WC, Stachel SE, Economides AN, Stahl N, Yancopolous GD \& Harland RM 1993 Neural induction by the secreted polypeptide noggin. Science 262 713-718. (doi:10.1126/science.8235591)

Livak KJ \& Schmittgen TD 2001 Analysis of relative gene expression data using real-time quantitative PCR and the 2(-Delta Delta $C(\mathrm{~T}))$ method. Methods 25 402-408. (doi:10.1006/meth.2001.1262)

Marsters P, Kendall NR \& Campbell BK 2003 Temporal relationships between FSH receptor, type 1 insulin-like growth factor receptor, and aromatase expression during $\mathrm{FSH}$-induced differentiation of bovine granulosa cells maintained in serum-free culture. Molecular and Cellular Endocrinology 203 117-127. (doi:10.1016/S0303-7207(03)00093-5)

Mason H 2000 Function of the polycystic ovary. Human Fertility 3 80-85. (doi:10.1080/1464727002000198741)

Michos O, Panman L, Vintersten K, Beier K, Zeller R \& Zuniga A 2004 Gremlin-mediated BMP antagonism induces the epithelial-mesenchymal feedback signaling controlling metanephric kidney and limb organogenesis. Development 131 3401-3410. (doi:10.1242/dev.01251)

Mihm M \& Austin EJ 2002 The final stages of dominant follicle selection in cattle. Domestic Animal Endocrinology 23 155-166. (doi:10.1016/ S0739-7240(02)00153-4)

Miyazono K, Kusanagi K \& Inoue H 2001 Divergence and convergence of TGF-beta/BMP signaling. Journal of Cellular Physiology 187 265-276. (doi:10.1002/jcp.1080)

Nakamura T, Takio K, Eto Y, Shibai H, Titani K \& Sugino H 1990 Activinbinding protein from rat ovary is follistatin. Science 247 836-838. (doi:10.1126/science.2106159)

Norman RJ, Milner CR, Groome NP \& Robertson DM 2001 Circulating follistatin concentrations are higher and activin concentrations are lower in polycystic ovarian syndrome. Human Reproduction 16 668-672. (doi:10.1093/humrep/16.4.668)

Otsuka F, Moore RK, lemura S, Ueno N \& Shimasaki S 2001 Follistatin inhibits the function of the oocyte-derived factor BMP-15. Biochemical and Biophysical Research Communications 289 961-966. (doi:10.1006/ bbrc.2001.6103)

Pangas SA, Jorgez CJ \& Matzuk MM 2004 Growth differentiation factor 9 regulates expression of the bone morphogenetic protein antagonist gremlin. Journal of Biological Chemistry 279 32281-32286. (doi:10. 1074/jbc.M403212200)

Pereira RC, Rydziel S \& Canalis E 2000 Bone morphogenetic protein-4 regulates its own expression in cultured osteoblasts. Journal of Cellular Physiology 182 239-246. (doi:10.1002/(SICl)1097-4652(200002)182: $2<239:$ :AID-JCP13>3.0.CO;2-W)

Piccolo S, Sasai Y, Lu B \& De Robertis EM 1996 Dorsoventral patterning in Xenopus: inhibition of ventral signals by direct binding of chordin to BMP-4. Cell 86 589-598. (doi:10.1016/S0092-8674(00)80132-4)

Pierre A, Pisselet C, Dupont J, Mandon-Pepin B, Monniaux D, Monget P \& Fabre S 2004 Molecular basis of bone morphogenetic protein-4 inhibitory action on progesterone secretion by ovine granulosa cells. Journal of Molecular Endocrinology 33 805-817. (doi:10.1677/jme.1.01545)

Pierre A, Pisselet C, Monget P, Monniaux D \& Fabre S 2005 Testing the antagonistic effect of follistatin on BMP family members in ovine granulosa cells. Reproduction, Nutrition, Development 45 419-425. (doi:10.1051/rnd:2005031)

Reddi AH 2001 Bone morphogenetic proteins: from basic science to clinical applications. Journal of Bone and Joint Surgery. American Volume 83-A (Supplement 1) S1-S6.

Robertson DM, Klein R, de Vos FL, McLachlan RI, Wettenhall RE, Hearn MT, Burger HG \& de Kretser DM 1987 The isolation of polypeptides with FSH suppressing activity from bovine follicular fluid which are structurally different to inhibin. Biochemical and Biophysical Research Communications 149 744-749. (doi:10.1016/0006-291X(87)90430-X)

Sasai Y, Lu B, Steinbeisser H, Geissert D, Gont LK \& De Robertis EM 1994 Xenopus chordin: a novel dorsalizing factor activated by organizer-specific homeobox genes. Cell 79 779-790. (doi:10.1016/0092-8674(94)90068-X)
Sasai Y, Lu B, Steinbeisser H \& De Robertis EM 1995 Regulation of neural induction by the Chd and Bmp-4 antagonistic patterning signals in Xenopus. Nature 377 757. (doi:10.1038/377757a0)

Sauer MJ, Foulkes JA, Worsfold A \& Morris BA 1986 Use of progesterone 11-glucuronide-alkaline phosphatase conjugate in a sensitive microtitreplate enzymeimmunoassay of progesterone in milk and its application to pregnancy testing in dairy cattle. Journal of Reproduction and Fertility $\mathbf{7 6}$ 375-391. (doi:10.1530/jrf.0.0760375)

Shimasaki S, Moore RK, Otsuka F \& Erickson GF 2004 The bone morphogenetic protein system in mammalian reproduction. Endocrine Reviews 25 72-101. (doi:10.1210/er.2003-0007)

Shimonaka M, Inouye S, Shimasaki S \& Ling N 1991 Follistatin binds to both activin and inhibin through the common subunit. Endocrinology 128 3313-3315. (doi:10.1210/endo-128-6-3313)

Silva CC \& Knight PG 1998 Modulatory actions of activin-A and follistatin on the developmental competence of in vitro-matured bovine oocytes. Biology of Reproduction 58 558-565. (doi:10.1095/biolreprod58.2.558)

Smith WC, Knecht AK, Wu M \& Harland RM 1993 Secreted noggin protein mimics the Spemann organizer in dorsalizing Xenopus mesoderm. Nature 361 547-549. (doi:10.1038/361547a0)

Sudo S, Avsian-Kretchmer O, Wang LS \& Hsueh AJ 2004 Protein related to DAN and cerberus is a bone morphogenetic protein antagonist that participates in ovarian paracrine regulation. Journal of Biological Chemistry 279 23134-23141. (doi:10.1074/jbc.M402376200)

Sugino K, Kurosawa N, Nakamura T, Takio K, Shimasaki S, Ling N, Titani K \& Sugino H 1993 Molecular heterogeneity of follistatin, an activinbinding protein. Higher affinity of the carboxyl-terminal truncated forms for heparan sulfate proteoglycans on the ovarian granulosa cell. Journal of Biological Chemistry 268 15579-15587.

Sugino H, Sugino K, Hashimoto O, Shoji H \& Nakamura T 1997 Follistatin and its role as an activin-binding protein. Journal of Medical Investigation 44 1-14.

Tannetta DS, Fray MD, Wrathall JH, Bleach EC, Glencross RG \& Knight PG 1997 Effects of supplementary treatment with bovine growth hormone on hormonal and ovulatory responses to inhibin immunization in ewes. Journal of Reproduction and Fertility 110 255-262. (doi:10.1530/jrf.0. 1100255)

Tano M, Minegishi T, Nakamura K, Nakamura M, Karino S, Miyamoto K \& Ibuki Y 1995 Regulation of follistatin messenger ribonucleic acid in cultured rat granulosa cells. Molecular and Cellular Endocrinology 109 167-174. (doi:10.1016/0303-7207(95)03499-W)

Thomsen GH 1997 Antagonism within and around the organizer: BMP inhibitors in vertebrate body patterning. Trends in Genetics 13 209-211. (doi:10.1016/S0168-9525(97)01117-7)

Tuuri T \& Ritovs O 1995 Regulation of the activin-binding protein follistatin cultured human luteinizing granulosa cells: characterization of the effects of follicle stimulating hormone, prostaglandin $\mathrm{E}_{2}$, and different growth factors. Biology of Reproduction 53 1508-1516. (doi:10.1095/ biolreprod53.6.1508)

Walsh DW, Godson C, Brazil DP \& Martin F 2010 Extracellular BMPantagonist regulation in development and disease: tied up in knots. Trends in Cell Biology 20 244-256. (doi:10.1016/j.tcb.2010.01.008)

Welt C, Sidis Y, Keutmann H \& Schneyer A 2002 Activins, inhibins, and follistatins: from endocrinology to signaling. A paradigm for the new millennium. Experimental Biology and Medicine 227 724-752.

Zhang YQ, Kanzaki M, Shibata H \& Kojima I 1997 Regulation of the expression of follistatin in rat hepatocytes. Biochimica et Biophysica Acta 1354 204-210. (doi:10.1016/S0167-4781(97)00085-7)

Zimmerman LB, De Jesus-Escobar JM \& Harland RM 1996 The Spemann organizer signal noggin binds and inactivates bone morphogenetic protein 4. Cell 86 599-606. (doi:10.1016/S0092-8674(00)80133-6)

Zuniga A, Haramis AP, McMahon AP \& Zeller R 1999 Signal relay by BMP antagonism controls the SHH/FGF4 feedback loop in vertebrate limb buds. Nature 401 598-602. (doi:10.1038/44157)

Received 4 May 2011

First decision 2 June 2011

Revised manuscript received 2 August 2011

Accepted 5 August 2011 